Letras, Lima 48 (88-89): 110-134, 1985.

\title{
Para la interpretación del poema vanguardista"
}

(Lectura intertextual de "El reloj caido en el mar" de Neruda)

RAUL BUENO CHAVEZ

Las dificultades inherentes a la interpretación de textos líricos, producidas por la atención que dicha tarea debe dedicar a las estructuras fónica y gramatical de los discursos poéticos, se hacen mayores cuando se trata de interpretar poemas vanguardistas. En éstos, como sabemos, la desviación de la norma linguística y la experimentación verbal alcanzan grados sin precedentes, hasta hacer del poema un discurso agramatical, fragmetario, caótico, absurdo, ininteligible..., en que son posibles muchos sentidos o, en apariencia, ninguno. Por eso la interpretación de estos textos debe realizarse con un modelo ad-hoc, que dé cuenta-entre otros aspectos-y problemas - de la estructura básica del csentidol cextuali dehsistema de relaciones existentes entre los diversos componentes estructurales del poema y del funcionamiento de los recursos poéticos privilegiados por la escritura de vanguardia.

Las páginas que siguen, aplicadas al estudio de uno de los más destacados poemas de Pablo Neruda, pretenden ser la puesta en práctica de un modelo analític adecuado a la especificidad del discurso poético vanguardista, modelo que hemos tratado de ajustar en recientes cursos universitarios de interpretación textual y que aquí se muestra en una etapa previa a su formalización definitiva. Por otra parte, y en estrecha vinculación con el objetivo anterior, estas páginas inten-

* El presente trabajo forma parte de una investigación sobre la renovación del lenguaje poético en la vanguardia hispanoamericana, realizada en el Centro de Estudios Latinoamericanos "Rómulo Gallegos" (Caracas), entre enero $y$ junio de 1980. Agradezco a los profesores Nelson Osorio y Hugo Achugor de dicho Centro y ol profesor Desiderio Blanco de la Universidad de San Marcos de Lima, sus atinadas observaciones y sugerencias a la primera versión del trabajo. 
tan ilustrar el funcionamiento de algunos recursos practicados por la vanguardia poética hispanoamericana, en especial los de las figuras básicas del contenido poético, la metáfora y la metonimia (la primera privilegiada por nuestros ultraístas y creacionistas), que en el pocma de Neruda actúan como un sistema alegórico, cuyos elementos se encuentran fuertemente correlacionados e imbricados.

Amado Alonso dedicó algunas de sus mejores páginas al estudio de "El reloj caído en el mar" (1). Esa interpretación, buena para su tiempo y coherente con los postulados estilísticos que la animaban, aparece hoy ante nosotros cargada de intuicionismo y psicologismo, como toda la corriente estilística. La necesidad de una lectura moderna del poema, que revele las operaciones lógico-semáticas que organizan el sentido textual y demuestre el trabajo linguístico productur de la significación, pretendemos satisfacerla con la interpretación que sigue. Como es obvio, en ella encontrará el lector algunos de los tópicos tratados por Alonso: no podría ser de otro modo, pues el texto analizado así lo determina. Un cambio de método, en este caso y en casos como éste, no puede negar aquellos elementos de sentido impuestos por el texto a cualquier lectura, a todas las lecturas.

En lo que concierne al procedimiento analítico-explicativo utilizado en el prosente trabajo, diremos que busca inicialmente aquellas agrupaciones semánticas denominadas configuraciones discursivas (2); establece luego los modos de relación significacional entre ellas; revela a continuación sus articulaciones en diferentes estructuras "sintagmáticas" del contenido; se proyecta deductivamente hacia el estudio de algunas formas lingüísticas y poéticas destacadas por el contenido; considera los aspectos intertextuales (palabras, versos, construcciones, sentidos de otros poemas del libro) que refuerzan o precisan la actuación de ciertos elementós de la expresión co delecontenido textual; y, por último, con todo lo analizado se proyecta hacia la definición de las categorías ideológicas que gobiernan la organización discursiva y la instancia de la lectura "natural" del poema. No es un procedimiento que debamos seguir con meticulosidad religiosa, sino un patrón ajustable según los casos concretos.

El texto del análisis, el poema "El reloj caído en el mar", integra la sexta sección de la segunda parte (escrita entre 1931 y 1935) de Residencia en la tierra. Con las dos partes de este poemario (la primera escrita entre 1925 y 1931) Pablo Neruda se aparta del neoromanticismo de imágenes inéditas y delicadas que había caracterizado a su poesía inicial (Crepusculario, Veinte poemas de amor...), para

(1) Amado Alonso: Poesía y estilo de Pablo Neruda, Buenos Aires, Editorial Sudamerica, 1968 pp. 40-43.

(2) Cf.: A. J. Greimas: "Les octants, les acteurs et les figures" in: Chobrol et al.: Sémiotique norrative ef textuelle, Poris, Lorousse, 1973; p. 170. Uno explicitación del concepto greimasiono de "configuración discursiva", puede ser leída en: Blanco, Desiderio y Bueno, Roúl: Mefodología del análisis semiótico, Lima, Universidad de Limo, 1980; pp. 130 ss. 
entregarse más firmemente a la etapa vanguardista de su poética, guiada por el dictado onírico propio del surrealismo y la atracción poderosa de las metáforas insólitas de términos alejados (3), tan caras a la experiencia creacionista. Por ello los poemas de este libro presentan a menudo grandes dificultades de intelección y se resuelven muchas veces en la disonancia (4) de que hablaba Hugo Friedrich, a propósito de la gran lírica moderna, como una integración de hechizo (lo que cautiva) e ininteligibilidad.

"El reloj caído en el mar" es, pues, uno de esos oscuros y atrayentes poemas característicos de Residencia en la tierra, y su texto es el siguiente:

\section{El reloj caído en el mar}

Hay tanta luz sombría en el espacio

y tantas dimensiones de súbito amarillas, porque no cae el viento ni respiran las hojas.

5 Ess un día domingo detenido en el mar, un día como un buque sumergido,

ferozmente vestidas de humedad transparente.

una gota de tiempo que asaltan las escamas

Hay meses seriamente acumulados en una vestidura

10 que queremos oler llorando con los ojos cerrados, $\mathrm{y}$ hay años en un solo ciego signo del agua depositada y yerdé, hay la edad que tos dedos ni la luz apresaron, mucho más"estimablecque un abanicos roto,

15 mucho más silenciosa que un pie desenterrado, hay la nupcial edad de los días disueltos

en una triste tumba que los peces recorren.

Los pétalos del tiempo caen inmensamente como vagos paraguas parecidos al cielo,

20 creciendo en torno, es apenas

una campana nunca vista, una rosa inundada, una medusa, un largo latido quebrantado:

pero no es eso, es algo que toca y gasta apenas,

25 una confusa huella sin sonido ni pájaros un desvanecimiento de perfumes y razas.

(3) Véose en este mismo trabajo el apartado: "Realidades más o menos distantes".

(4) Hugo Friedrich: Estructura de la lírica modorna, Barcelona, Seix Barral, 1959; p. 14. 
El reloj que en el campo se tendió sobre el musgo y golpeá una cadera con su eléctrica forma corre desvencijado y herido bajo el agua temible que ondula palpitando de corrientes centrales.

\section{El tiempo disuelto en el mar}

El título del poema nos introduce en las dos líneas de sentido. por las que se conduce la legibilidad del texto: el mar y el tiempo. Estas dos nociones redundan muchas veces en el cuerpo del poema, mediante figuras cosmológicas y categorías de pensamiento allegadas por procedimientos metafóricos o metonímicos, que conforman dos grandes configuraciones discursivas (6):

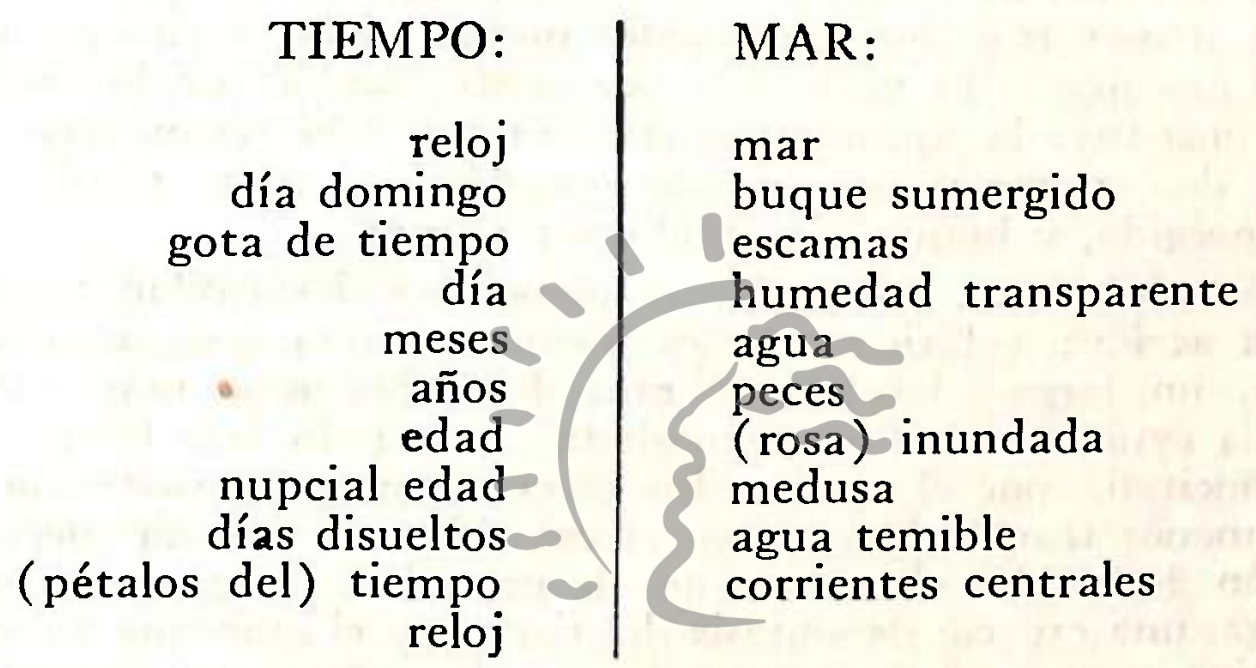

También el título nos ilustra sobre el tipo deSrelación entre las realidades Tiempo y Mar el tiempo (el reloj) cae y penetra en el mar, con lo que comienza el deterioro de la primera realidad, su paralización. El verso "un día como un buque sumergido", constituye una de las distintas variantes figurativas de esa penetración; contribuye por igual a las significaciones de daño y detenimiento (remite a un barco naufragado y a su estatismo consecuente) y metaforiza de un segundo modo al tiempo (día = buque).

El verso "una gota de tiempo que asoltan las escamas" es otra variante de la acción anunciada por el título. Obviamente, ha de estar el tiempo inmerso en el mar para que lo asalten los peces, que un procedimiento metonímico del tipo pars pro toto trae a cuenta a par-

(5) Pablo Neruda: Residencia en la tierra, Buenos Aires, Editorial Losada, 1958; pp. 175-176. Las citas de otros poemas de Neruda, han sido tomadas de esta misma edición.

(6) Según el criterio greimasiano, las configuraciones discursivas consisten de redes de figuras nucleares o conjuntos sémicos logrados a partir del cosmos. Nuestra variante consiste en incluir dentro de las configuraciones a ciertas categorías de pensamiento, como los meses, los años y las edades, que no pueden ser adscritas a la noción de clasema y que tienen una cierta conducta cosmológica, a partir de una especie de "cosificación" que les asigna la sociedad. 
tir de la sola mención de sus escamas. Los versos "hay la nupcial edad de los días disueltos, en una triste tumba que los peces recorren" desarrollan el mismo contenido que acabamos de comentar, sin el componente de ferocidad ("asaltan") y con el agregado de remitir al buque sumergido ("tumba que los peces recorren") de la segunda estrofa. Finalmente el verso "corre desvencijado y herido bajo el agua temible", constituido como predicación del sujeto reloj, es otro modo de referir la intromisión del tiempo en el mar y es, además, una clara redundancia del título.

El poema realiza también la segunda posibilidad de la relación, esto es, la penetración del mar en el tiempo. El verso -ya comentado- "una gota de tiempo que asaltan las escamas", constituye la primera muestra de esta segunda acción, muestra en que debe recomponerse el mar tras dos operaciones metonímicas: escamas por peces, y peces por mar. El verso "en una triste tumba que los peces recorren", constituye la segunda muestra, en que debe reconocerse al tiempo tras dos sucesivas operaciones metafóricas: triste tumba por buque sumergido, y buque sumergido por tiempo.

Más sutilmente, las siguientes menciones desarrollan también esa segunda acción: (el tiempo) "es apenas... una rosa inundada, una medusa, un largo! latido quebrantado". Decimos más sutilmente, pese a la evidencia de "rosa inundada", pensando más bien en la medusa concitada por el verso. En efecto, por su consistencia acuosa, más o menos translúcida, y por su colorido, ella es una suerte de integración de los dos elementos que le preceden, la rosa y el agua que la aniega, una especie de síntesis del tiempo y el mar que se encubren metafórica y metonímicamente tras lambas designaciones. Con "latido quebrantado" el tiempo resulta ser una pulsación fallida; pero necesariamente la Jpulsación delalgún líquido, "pues de otro modo 110 sería latido. Si se repara en la progresión de esta cadena de menciones, se verá que la acción de penetrar el agua en los símiles del tiempo (reloj, buque, rosa, medusa, latido) es una aproximación gradua! a la consustanciación del mar y el tiempo, hecho sobre el que habremos de volver.

En cuanto a las dos condiciones que caracterizan al tiempo que el texto poetiza, el detenimiento y el deterioro (7), vemos que éstas aparecen de modo redundante en el poema, por medio de figuras que interesan directamente al tiempo o corresponden a sus representantes metafóricos o metonímicos. Esas figuras entrañan la negación del movimiento o de la acción, la inmovilidad, o al menos la apariencia de inmovilidad, en los versos siguientes (los subrayados son nuestros):

(7) No hablamos, por el momento, de un tiempo que deteriora (motivo largamente tratado por la literatura occidental y por Neruda en su Residencia....), sino de un tiempo deteriorado, sometido a la acción de otro mayor que, a partir de un verso del poema "Tirania" de Neruda, denominamos "tiempo total". 
- porque no cae el viento

ni respiran las hojas.

-Es un día domingo detenido en el mar, un día como un buque sumergido, unna gota de tiempo.

- Hay meses seriamente acumulados

-y hay años (acumulados) en un solo ciego signo del agua depositada y verde,

-Los pétalos del tiempo

-latido quebrantado

Las figuras que integran el componente semántico del deterioro, de modo activo o pasivo, las encontramos en los siguientes versos o fragmentos:

-buque sumergido

- una gota de tiempo que asaltan las escamas ferozmente vestidas

-... agua

depositada y verde

-abanico roto

- pie desenterradoiblioteca de Letras

-días disueltos

- triste tumba

"Jorge Puccinelli Converso"

- rosa inundada

-un largo

latido quebrantado

-algo que toca y gasta apenas

- una confusa huella sin sonido ni pájaros

-un desvanecimiento de perfumes y razas

-(el reloj) corre deszencijado y herido

Sólo para los efectos de una aprehensión global de los diferentes contenidos hasta aquí considerados, proponemos el siguiente enunciado que los resume y, en cierto modo, los sintagmatiza: el tiempo cae al mar y allí se frena y deteriora. A este enunciado le falta, sin embargo, una precisión: el deterioro del tiempo culmina en el texto con 
la disolución ("hay la nupcial edad de los días disueltos"), con la pérdida de su integridad y límites ("confusa huella"), con el desleimiento ("un desvanecimiento de perfumes y razas"), aspectos éstos que ya vimos como una consustanciación del mar y el tiempo y que tendrán cabal sentido tras la averiguación de la naturaleza del mar poetizado. Son pues, rasgos característicos del factor tiempo, en el poema como en las formaciones discursivas de los pueblos, la fugacidad, la inmaterialidad y la inasibilidad, condiciones que bien pueden set detectadas en conjunto en un verso como: "hay la edad que los dedos ni la luz apresaron".

\section{Tiempo humano versus tiempo total}

La relectura del poema nos permite observar un componente humano del tiempo en cuestión. En principio, las fracciones del tiempo enumeradas en el texto nos avisan de una convención social: la que acuerda sumar los días en semanas, las semanas en meses, los meses en años, los años en edades. Por otra parte, el reloj mismo nos habla de la necesidad humana de mensurar las fracciones más pequeñas del tiempo. Pero aparte de estos evidentes indicadores que nos obligan a suponer una isotopía humana a lo largo del texto, el poema es explícito en ciertas relaciones entre el flujo del tiempo y la experiencia humana concreta, a través de los versos: "Hay meses seriamente acumulados en una vestidura que queremos olep llorando con los ojos cerrados", y "hay la nupcial edad de los días disueltos", y también "El reloj que en el campo se tendió sobre el musgo/y golpeó una cadera con su eléctrica forma' corre desvencijado y herido bajo el agua temible".

La acción dañina del mar,Cejercida sobre experiencias y objetos teñidos de contenidōohumano, noelès Calgo formulado exclusivamente por "El reloj caído en el mar", sino una significación iterativa en $R e$ sidencia en la tierra. Así, en "Ausencia de Joaquín", las aguas del mar que reciben el cadáver del amigo muerto "saltan y salpican estas aguas,/ sobre mí salpican estas aguas, y viven como ácidos". Luego, en "El sur •del océano", la luna desciende en el mar "carcomida por los gritos del agua" y "arrastrando su cargamento corrompido,/ buzos, maderas, dedos". Y en "Josie Pliss" el mar, una vez más cargado de poder corrosivo, con "su ácido degradado, su ola de peso pálido/ persigue las cosas hacinadas en los rincones del/alma".

Hay poemas de Residencia... que detallan series de utensilios y valores humanos caídos en el mar, sumergidos en el océano (8), arras-

(8) El lector atento habró notado que algunos fragmentos con inclusión del término "océano" los adjudicamos al caso de "mar". La razón de ello reposa no sólo en la sinonimia de ambos vocablos, sino en que, dentro de la lengua poética de Neruda, "mar" y "océano" remiten al mismo referente y se cargan de los mismos contenidos simbólicos. Prueba de ello está en "El sur del océano" en que se usa indistintamente ambos términos, aunque con una significativa preferencia (en la proporción de siete a cuatro) por "mar". 
trados hacia las profundidades. También en ellos la caída de los objetos y entidades humanas marca el inicio de su degradación. En este sentido, destaca el poema "Melancolía en las familias" en que, tras la mención al poder perforante del océano, se consideran "grandes extensiones hundidas /.../ cosas caídas, medallas, ternuras, paracaídas, besos". Y, más aún, el poema "La calle destruida", en que la fuerza deteriorante del agua, unida a la del aire y otros factores negativos, toca zonas notablemente cercanas a "El reloj caído en el mar" (los subrayados que siguen son nuestros):

\author{
gastan las cosas, tocan \\ las ruedas... \\ ...mientras a lo profundo \\ caen llaves, relojes, \\ flores asimiladas al olvido.
}

La condición nociva del mar, en el poema sometido al análisis compromete a los peces que lo pueblan, haciéndolos habitantes hambrientos y feroces, según pueden entenderse con la lectura de los versos séptimo y octavo: "... escamas/ ferozmente vestidas de humedad transparente". Lo mismo ocurre en "El sur del océano", en que aparecen "peces de ensangrentadosi dientes" y "mordeduras de pescados siniestros"; y en "Maternidad", en que por su carácter maligno se repudia doblemente (primero por su nombre y luego por su representante metonímico) a los peces del mar por donde ha de pasar aquella que se precipita "hacia la maternidad": "Por corredores donde nadie ha muerto/ quiero que pases, por un mar sinpeces/ sin escamas, sin náufragos".

Con las constataciones antefrores, la semanticidad global de "El reloj caído en cl mar", puede ser articulada y precisada mediante un enunciado como el siguiente: el tiempo humano cae en el mar temible y allí se obstaculiza, deteriora y disuelve. En otras palabras: la experiencia del hombre (lo vivido) se hace nada... en el mar (9). Falta precisar la intención semántica del mar, pues es evidente que la función poética que se le tiene asignada es la de ofrecerse como un símbolo, como término sustitutorio dentro de una relación metafórica.. Conviene que investiguemos en esa dirección.

(9) Con ánimo de echar un poco de luz sobre uno de los casos concretos que puede cubrir el valor genérico del tiempo humano, proponemos la siguiente línea de lectura a manera de hipótesis. Atendiendo a uno de los rasgos significacionales de la expresión "nupcial edad", el tiempo extinguido ("días di. sueltos") sería el de la juventud. Mas, atendiendo al valor socializado de la misma expresión, el tiempo ido sería el de las bodas, el de la experiencia matrimonial. Hay ciertos elementos intertextuales que apoyan esta segunda posibilidad de lectura, y ellos están contenidos en dos poemas de la primera parte de Residencia en la tierra: "Arte poética" y "Tango del viudo'. En ambos el poeta, transparentado en el yo lírico, se asigna la condición de viudo y desa- 
Todo poemario organizado según la voluntad del poeta, entraña dos tareas de composición, en niveles diferentes. La primera apunta a la constitución del poema; la segunda, a la construcción del poemario. En la segunda son vinculados poemas y secciones de poemarios entre sí, de modo que una corriente semántica unificadora y genérica circule en el conjunto y le otorgue unidad. Por eso determinados contenidos trascienden los límites del poema y redunda periódicamente a lo largo del poemario. Este hecho hace legítima la lectura intertextual, a la que ya hemos apelado para descubrir las valencias semánticas de ciertos elementos textuales de "El reloj...", y a la que apelaremos luego para averiguar la naturaleza simbólica del mar en el poe. ma que nos ocupa.

Por fortuna, Residencia en la tierra contiene dos claros enunciados textuales que especifican la naturaleza poética del mar (del océano). En "Tiranía", un poema de la primera parte, aparece el verso "Un tiempo total como un océano"; y en "El sur del océano", poema que se hace clave para la lectura de "El reloj...", encontramos los versos: "...todas las aguas van a los ojos fríos/ del tiempo que debajo del océano mira". No cabe, pues, duda alguna: el mar (o el océano, pues ambos términos son usados indistinta y reiteradamente en "El sur...") está asociado al tiempo y, más aún, equivale al tiempo. No se trata ya del tiempo parcelado, ajustado a los alcances humanos y por doquier ligado a experiencias concretas - tiempo que hemos visto fracasar ante el mar-, sino de un tiempo inmenso, inagotable, sobrehumano, ahistórico... Se trata, en suma, y como bien lo dice el verso de "Tiranía", de "un tiempo total".

Con los datos precedentes nos es posible reformular el enunciado metalingüístico correspondiente al sentido de "El reloj caído en el mar" del modo siguienté: el trempohumano se anula"y pierde en el tiempo total. Dicho de otra manera, la pequeñez y la inconsistencia del primero ("gota de tiempo", "pétalo") nada pueden ante la inmensidad, la inabarcabilidad y la infinitud del segundo. Es más, el tiempo oceánico destruye sin gastarse, corre sin dañarse, rechaza toda posibilidad de deterioro de sí mismo. En este sentido resulta sumamente esclarecedor el poema "El fantasma del buque de carga". Allí el viejo barco "de podridas maderas y hierros averiados", habitado por un fantas-

rrolla el tópico de la vida solitaria ligada a la viudez ("He llegado otra vez dice en el 'Tango...'- a los dormitorios solitarios,/ a almorzar en los restourantes comida fría, y otra vez/tiro al suelo los pantalones y las camisas,/ no hay perchas en mi habitación, ni retratos de nadie en/ las paredes"). En el "Tongo..." el poeta llega incluso a desarrollar una explícita lamentación por la ausencia de su compañera, a la que debió abandonar y a quien quisiera recuperar de algún modo ("Daria este viento de mar gigante por tu brusca respiración..."). Como dijimos líneas arriba, ésta podría ser una de las experiencias concretas cubiertas por el tiempo humano (el reloj, las gotas, los pétalos, los paraguas...) poetizado con rasgos de deterioro y extinción por "El reloj caido en el mar". No pretendemos especificar el contenido genérico del tiempo humano a este solo hecho. 
ma "con su rostro sin ojos" y "con ojos que la muerte preserva", navega por un mar de aguas invulnerables y dañinas, desprovistas de costumbre y tiempo humanos:

Sin gastarse las aguas, sin costumbre ni tiempo, verdes de cantidad, eficaces y frías, tocan el negro estómago del buque y su materia lavan, sus costras rotas, sus arrugas de hierro: roen las aguas vivas la cáscara del buque,

Desde la perspectiva del tiempo humano, el tiempo total aparece entonces ligado al olvido (recordemos los versos de "La calle destruida": "...mientras a lo profundo/ caen llaves, relojes,/ flores asimiladas al olvido") y, más aún, a la muerte: en el poema titulado "Colección nocturna" nos damos con estos versos que ya nos resultan familiares:

Camaradas cuyas cabezas reposan sobre barriles, en un desmantelado buque prófugo, lejos, amigos míos sin lágrimas, mujeres de rostro cruel: la medianoche ha llegado y un gong de muerte golpea en torno mío como el mar.

En la elegía "Alberto Rojas Jiménez viene volando", reaparecen asociados al mar, la muerte, los barcos y los peces; y allí vuelve a golpear el mar, como en "Ausencia de Joaquín", como en "Colección nocturna", con notas funerales: "y el agua de los muertos me golpea".

Al comenzar este análisis, habíamos observadoel estatismo característico del tiempo humanoen "el reloji caído en el "mar". Entonces hicimos una relación más o menos detallada de los diversos enunciados textuales que sostienen la isotopía estática del poema, dejando deliberadamente de lado, hasta un momento más oportuno, la consideración de algunos enunciados (en verdad pocos) que entrañan la isotopía contraria. Ahora estamos ya en condiciones de explicar la función del dinamismo comprendido por ciertos versos del poema que nos ocupa. De estos versos, algunos contribuyen a la caracterización semántica del tiempo humano (v.gr.: "los pétalos del tiempo cáen inmensamente"); otros, a la del tiempo total (v.gr.: "... asaltan las escamas"). La diferencia radica en los rasgos de significación que acompañan a la dinámica del tiempo total. En efecto, en este caso el dinamismo es atroz, está cargado de malignidad y poderío, lo que puede observarse con claridad en los versos finales del poema: "...agua temible/ que ondula palpitando de corrientes centrales". La siguiente sintagmatización de contenidos se ofrece, entonces, como una posibilidad de lectura de toda esta problemática. Ante la poderosa y avasallante dinámica del tiempo total, la del tiempo humano se neutraliza ("un día como un buque sumergido") y se pierde ("un desvanecimiento de 
perfumes y razas"). Por eso el tiempo-mat es temible y la presencia del océano provoca esa especie de miedo pánico significado por "El reloj caído en el mar" y por muchos versos de Residencia en la tierra. Porque, ingresado en el tiempo total, el tiempo de la experiencia humana encuentra deterioto (el reloj "corre desvencijado y herido"), encuentra olvido, muerte. Allí muere también la memoria (esa memoria eidética que en el poema permite la existencia de los versos: "Hay meses seriamente acumulados en una vestidura/ que queremos oler llorando con los ojos cerrados"), que por estar ligada al hombre es precaria, dezlenable ("hay la edad que los dedos ni la luz apresaron").

Con todo lo visto podemos decir que "El reloj caído en el mar" se ofrece como una negación de los poemas de carpe diem. En éstos se propone la posibilidad de retener el día (cogerlo), mientras que en "El reloj..." está de algún modo significado que no es posible una apropiación del tiempo humano, que todo intento desplegado por el hombre para apropiạrse de su tiempo es inútil y está condenado al fracaso.

Al volver a las páginas que Amado Alonso dedicó a este poema vemos que la intuición del estilista español no estuvo lejos del conocimiento central of recido por esta parte de nuestro trabajo. Dijo Alonso, con expresión que ahora tiene para nosotros un sentido más rico y más complejo: "el pensamiento poético central de 'El reloj caído en el mar' es la visión sentimental de la medida caída en lo inmensurable, el reloj caído en la eternidad" (10), y dijo a propósito de la consistencia poética de la medusa concitada por el poema: "agua en el agua (tiempo en el tiempo)" (11). Le faltó especificar la naturaleza y las proyecciones significacionales de ambos tiempos y determinar la sintagmáticả osemántica queelos aengloba. Le faltó también explicar los mecanismos dingüístico-semánticos productores de la significación propuesta por "El reloj caído en el mar". Estas explicables limitaciones y ausencias nos hacen volver al texto, para leerlo con ojos críticos.

\section{El juego de las metáforas}

Es sabido que los escritores hispanoamericanos de vanguardia concedieron, en sus manifiestos y en su práctica poética, gran importancia a la metáfora. Así, en más de una ocasión, el Jorge Luis Borger ultraísta postuló la "reducción de la lírica a su elemento primordial: la metáfora", y aun concibió el poema vanguardista como una sucesión de metáforas inéditas: "los poemas ultraicos — decía el joven Borges - constan, pues, de una serie de metáforas, cada una de las cuales tiene sugestividad propia y compendiza una visión inédita de

(10) A. Alonso: Op. Cit.; p. 40.

(11) Ibid.; p. 41. 
algún fragmento de la vida" (12). Unos diez años antes Vicente Huidobro, al reflexionar sobre "el arte del sugerimiento" (13), postulaba una poesía que no plasmase los contenidos de manera directa y brutal, sino que los sugiriese; consecuentemente, su ejercicio poético se condujo a través de la figura o tropo que mejor puede realizar una estética de la sugerencia, la metáfora, desarrollándola en usos tan variados que casi agotan las posibilidades del recurso. Aquellos jóvenes iconoclastas - "con fe, con esperanza y sin caridad"- que, en la Caracas de 1928 y a través del manifiesto "Somos", proclamaron su adhesión al "arte nuevo", vieron que sugerencia y metáfora son términos de la misma ecuación: "El arte nuevo - decían - no admite definiciones, porque su libertad las rechaza..."; y más adelante: "su último propósito es sugerir, decirlo todo con el menor número de elementos posibles (de allí la necesidad de la metáfora y la imagen duple y múltiple)" (14).

Hemos juzgado necesario espigar las cita anteriores, porque en gran medida corresponden a la singularidad del poema de Neruda que nos ocupa. En efecto, "El reloj caído en el mar" se realiza en una gran cadena de metáforas, casi todas destinadas a la intuición del tiempo humano, de las que por lo menos quince representan las diferentes modalidades de un trabajo poético en el orden de los sustantivos y tienen como clemento básico el factor temporal. Las demás - no menos de diez- constituyen metáforas de otra índole, logradas con operaciones sustitutorias en los órdenes del adjetivo (seis) y del verbo (cuatro), que modulan sentidos indirectamente vinculados al tiempo (15).

De las metáforas nominales del texto, dos llegan al grado de la sustitución absoluta $(b b$ en lugar de $a$ el relojen lugar del tiempo humano; el mar en lugar del tiempo total). Las demás se quedan en

(12) J. L. Borges: "Ultraísmo" in: Oscar Collazos (editor). Los vanguardismos en la América Latina, La Habana, Casa de las Américas. (Serie Valoración Múltiple), 1970; p. 195.

(13) V. Huidobro: Pasando y pasando in: Obras completos de Vicente Huidobro. ("Prólogo" por Hugo Montes), T. I., Santiago, Editorial Andrés Bello, 1976; pp.

(14) In: válvula, Caracas, enero de 1928.

(15) Distinguimos metófora de operación metafórica. Por esta última entendemos la sustitución de un elemento del sintagma por otro que pertenece al mismo paradigma del elemento sustituido. Pertenecen al mismo paradigma las unidades lingüísticas que pueden conmutarse entre sí, en un sintagma dado. No todas las sustituciones metafóricas producen metáforas. Así la sustitución de "grande" por "blanca' en "la luna blanca" no origina una metófora. Entendemos por metófora la sustitución que produce un enunciado denotativamente absurdo, sin correlato cosmológico: "la luna plegable". Según el lugar sintagmótico en que ocurra la sustitución, podemos tener: metóforas nominales, adjetivales y verbales. Esta clasificación tiene ya alguna bibliografía, entre la que destaca el libro de Christine Brooke-Rose: A Grammar of Metophor (Londres, 1958). Cf.: Albert Henry: Métonymie et métophore, Paris, Klincksieck, 1971; pp. 54 s. y 81 ss. 
alguno de los grados del proceso sustitutorio, sintagmatizando los elementos de la relación metafórica en una identificación explícita ( $a$ es $b$; el tiempo es una rosa inundada, una medusa, un largo latido...) o una comparación ( $a$ es como $b$; un día como un buque sumergido) (16).

Las dos metáforas que actualizan la posibilidad absoluta de la sustitución metafórica se dan en el título del poema. Dada su situación privilegiada, al presidir el texto y al constituirse en anuncio de su desarrollo temático, ellas superan su mera condición metafórica para constituirse en elementos de una alegoría. Esta figura, entendida como un juego imbricado y ordenado de metáforas, no sólo establece un tipo de relación entre las dos metáforas capitales del texto (una realidad ha caído en otra, se ha sumergido en clla), sino que organiza el conjunto de las diferentes metáforas que tienen su lugar en las estrofas segunda a cuarta del poema. Ya hemos visto cómo ese conjunto metafófico desarrolla en distintas modalidades y tonos la intención semántica contenida en el título. Como resultado de la secuencia metafórica de ese conjunto se define el estatuto alegórico del título o anuncio del poema. En efecto, la expresión "el reloj caído en el mar" relacionada con todo el cuerpo del texto no puede ser solamente leída en su valor denotativo, como un acontecer constatable empíricamente; un determinado y concreto reloj caído en el mar real; debe, en cambio, ser leída en un horizonte de sentido afirmado en el nivel de las connotaciones producidas por el texto a través de todas sus menciones y figuras: así se da cuenta de,un acontecer noológico, espiritual, por el que los elementos del tiempo impregnados de nota humana caen ( $y$ se anulan y pierden) en el tiempo vasto, inabarcable, inconmensurable. CPor ello se puede señalar aquí que las

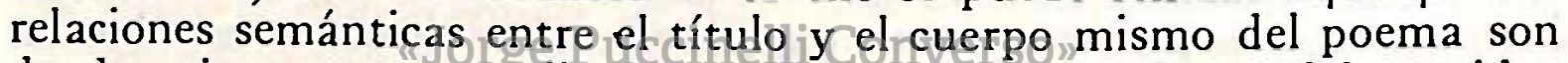
de dos tipos, correspondientes a distintas orientaciones del sentido: con relación al título, el texto del poema se muestra como el conjunto productor de nuevos valores significacionales para los términos que intervienen en la constitución de la frase y aun, para el conjunto gramatical que ellos conforman. Y, en la otra orientación, con relación al cuerpo mismo del poema, el título cumple la función de anticipación semántica, y aun la de colector y organizador de los diferentes sentidos producidos por las menciones y figuras que articulan ese cuerpo textual.

Para dar una seña de la compleja red de relaciones existentes entre las metáforas del texto en sí, con sus imbricaciones dentro de un sistema jerárquico y sus interacciones, consideremos a continuación la constitución de algunos versos del poema. En el v. 7, "una gota de

(16) Utilizamos aquí, para una rápida caracterización de las metáforas nominales más evidentes, las conocidas formulaciones de Lázaro Carreter sobre las metáforas pura e impura. Cf.: Fernando Lázaro Carreter: Diccionario de términos filológicos, Madrid, Gredos, 1962; p. 275. 
tiempo que asaltan las escamas", podemos ver el elemento $b$ de una relación metafórica sintagmatizada del tipo comparación (imagen), que nos remite a un elemento a gramaticalmente elidido-por estar presente en el verso anterior ("un día como..."). Este verso entraña, por otra parte, dos procedimientos metafóricos nominales. El primero, del tipo sustitutorio, hace al tiempo equiparable al agua, pues no otra cosa podría ser traída a cuenta, a partir de las configuraciones hídricas del texto, por la expresión paralexematizada "una gota de...":

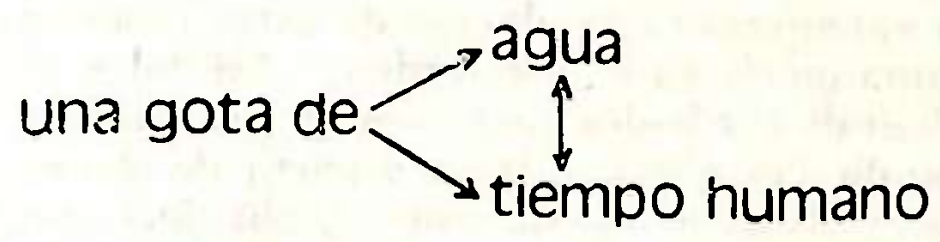

El segundo procedimiento, del tipo metonímico-sustitutorio, hace equivalente las escamas y el tiempo, a través de una cadena metonímica del orden pars pro toto que remata en una metáfora tradicional (17):

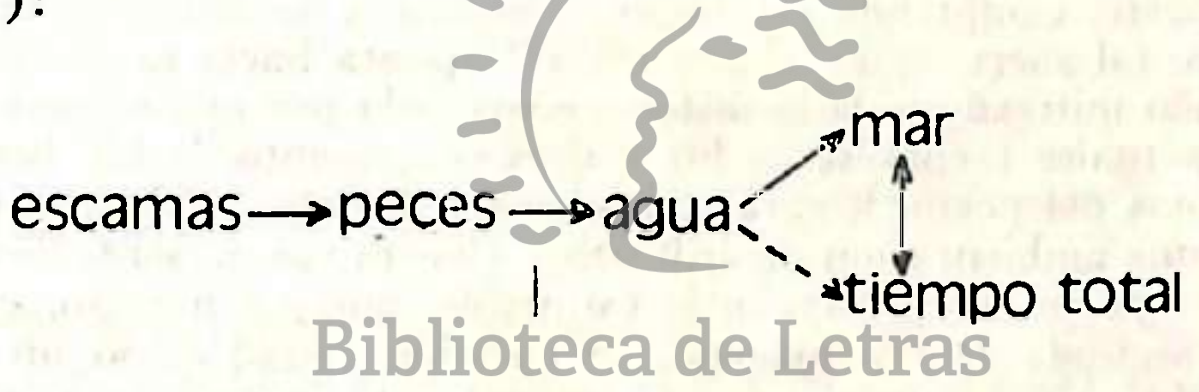

El mismo verso "comprende, además, una sustitución metafórica verbal, en que la acción "asaltan", correspondiente a escamas-peces, remite a la acción "disolver" (considérese el v. 16 con sus "días disueltos"), pertinente al mar en que concluye la secuencia metonímica; y también remite a la acción "desvanecer" (considérese el v. 26: "un desvanecimiento de perfumes y razas"), pertinente al tiempo concitado metafóricamente por el mar. El reemplazo de "disolver" $y$ "desvanecer" por "asaltar" configuraría, pues, una de las metáforas verbales del texto, ligada firmemente al sistema metafórico del poema.

Entre los versos 13 a 15 del poema, encontramos dos metáforas de comparación en que se expresa la relación jerárquica de superioridad de uno de los términis metafóricos sobre el otro. Los versos "hay la edad que los dedos ni la luz apresaron,', mucho más estimable que un abanico roto" entrañan la comparación implícita entre la edad (el tiempo humano) y el abanico roto, con un énfasis de semanticidad volcado hacia el primer término de la comparación. El siguiente enun-

(17) Para una caracterización de la metáfora tradicional, véase el punto "Realidades más o menos distantes" de este trabajo. 
ciado puede contribuir a explicar el tipo de relación metafórica existente en esos versos: la edad es como un abanico roto (deteriorado, inútil), pero mucho más estimable. Por otra parte, el verso "mucho más silenciosa que un pie desenterrado", en relación con la edad presentada en el verso 13, establece una relación análoga a la anterior, que podemos enunciar así: la edad es como un pie desenterrado (muerto, profanado), pero mucho más silenciosa. Ambas metáforas se encuentran ligadas por el hecho de compartir semántica y gramaticalmente el término a (edad) y también por la estructura paralclística en que se desarrollan (piénsese en las imágenes duples invocadas por el manifiesto "Somos") (18).

El trabajo vanguardista productor de estas imágenes hace de cada elemento $b$ una metáfora de otro orden. Así "abanico roto" y "pie desenterrado" han de ser leídos como significantes de otras realidades, innominadas, implícitas, que la crítica, a partir de elementos textuales, podría detectar. "Abanico" y su función, abanicar, remiten metonímicamente a sofocación y falta de brisa, fenómenos que forman parte del referente del poema analizado y que en cierto modo están adelantados por el verso 3: "porque no cae el viento" (nótese de paso que "caer" constituye una metáfora verbal por "soplar"). "Roto", por su parte, comprende los rasgos semánticos de deterioro e inutilidad. De tal suerte que "abanico roto" apunta hacia la inutilidad de una acción mitigadora de la disforia provocada por una situación y un tiempo actuales (repárese en los verbos en presente de las dos primeras estrofas del poema), caracterizados por la inmovilidad, la falta de brisas y una ambientación amarillenta. Contra ese presente los versos 13 y 14 oponen un tiempo más estimable, aunque huidizo, extinto.

La segunda dellas imágenes en cuestión (edad como un pie desenterrado) incluye'un término $b$ generador de un nuevo procedimiento metafórico basado en una evidente cadena metonímica. En efecto, "un pie desenterrado" remite a cadáver, que a su vez remite a mucrte (repárese en la "triste tumba" del v. 17, que contribuye a instalar en el texto de manera inequívoca la isotopía de la muerte). La lección final de esta imagen jerarquizada, en el sentido de una edad más silenciosa que la muerte, conduce, por vías de la hipérbole, hacia la intuición de un tiempo, que ya no puede manifestarse por estar definitivamente perdido.

(18) La imagen jerarquizada no es nueva en la historia de la literatura. Ya Góngora, por ejemplo, la había practicado cuatro veces en su bello soneto "Mientras por competir...". Así, al escribir "y mientras triunfo con desdén lozano/ del luciente cristal tu gentil cuello" establecía una comparación metafórica en que uno de los elementos tiene un manifiesto privilegio sobre el otro. El siguiente enunciado metalingüístico hace clara lo relación comparativa, con énfasis de positividad (por vias de la belleza) en uno de los términos metafóricos: tu gentil cuello es como el luciente cristal, pero más bello, ya que triunfa sobre éste. La diferencia entre las imágenes tácitas de Góngora y Neruda estriba en una jerarquización siempre positiva en las primeras, contra una jerarquización negativa ("más silenciosa que...") en una de las segundas. 
Para terminar este apretado análisis de la estructura y el funcionamiento de las metáforas de "El reloj...", y sin considerar el caso de las metáforas adjetivales (19) del texto ("luz sombría", "dimensiones amarillas", "rosa inundada", "eléctrica forma", etc.), observemos un encabalgamiento que comprende una complicada estructura metafórica. Entre los versos 7 y 8 leemos "escamas/ ferozmente vestidas de humedad transparente". No vamos aquí a repetir el proceso metonímico-metafórico generado por "escamas"; pero sí vamos a recordarlo para hacer claro cómo es pertinente al sentido del verso \& el elemento "peces" actualizado en primer lugar por la cadena metonímica, en tanto que es pertinente al sentido general del poema el elemento "tiempo total" actualizado metafóricamente por el "mar" en que concluye la secuencia metonímica. Este es, pues, un caso en que una misma base metafórica sirve a instancias diferentes del sentido textual, a través de los distintos niveles de la estructura que soporta. Encontramos el mismo efecto luego, con la metáfora verbal "vestidas", que remite al participio "rodeados" pertinentes a "peces" y al participio "integrado" correspondiente a "mar":

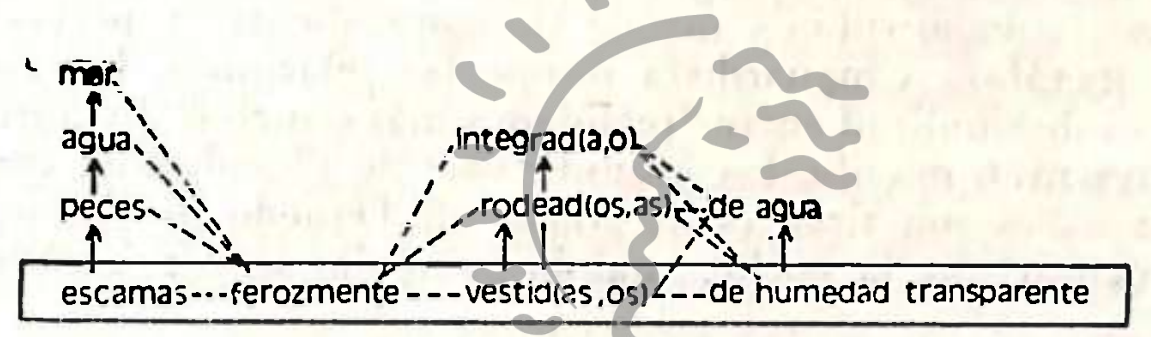

La expresión "humedad transparente" constituye, por su parte, una metáfora perifrástica de agua, o lo que es lo mismo, una catálisis metafórica del nombre agua, que gracias la carácterodeteriorante de la humedad beneficia a uno de los sentidos primordiales sostenidos por el poema. La expresión virtual: "mar ferozmente integrado de agua", desprendida por vías del análisis que explicita el esquema anterior, no está lejos de la significación planteada por los versos del encabalgamiento analizado y del sentido que organiza buena parte del poema. En prueba de ello está la mención final del poema con las palabras: "agua temible/ que ondula palpitando de corrientes centrales".

El juego correlacionado, imbricado e interactuante de metáforas no es privativo, ciertamente, de la poética vanguardista. Pero, sin lugar a dudas, constituye uno de sus recursos de privilegio. $Y$ aunque la propuesta de las metáforas duples y múltiples vinculadas al arte nuevo la formulara primero Marinetti (20), tiene importancia histó-

(19) La metáfora adjetival puede cubrir una diversidad de figuras vinculadas a la adjetivación, como el oximoron, el desplazamiento calificativo (hipálage), el epiteto inusitado, la sinestasia simbolista, etc.

(20) En su "Manifiesto técnico de la literatura futurista" del 11 de ma- 
rica la invocación contenida en el manifiesto "Somos" de la revista caraqueña válvula, por haber expresado con claridad una de las características de nuestra vanguardia literaria, que en ciertos casos, como el de Neruda en el poema que nos ocupa, muestra extremadas las posibilidades del recurso.

\section{Realidades más o menos distantes}

En un trabajo de juventud Pierre Reverdy, inspirado sin duda por Marinetti (21), teorizó sobre la naturaleza y el caráter de la metáfora vanguardista, a la que denominaba imagen. Según esa reflexión la poética de vanguardia establece vínculos metafóricos entre términos alejados - que no comparten evidentes rasgos de semanticidad- originando así imágenes más significativas y sugerentes: "Mientras más lejanas y justas - decía Reverdy - sean las relaciones de las dos realidades aproximadas, la imagen será más fuerte: tendrá mayor potencia emotiva y realidad poética" (22). A diferencia, pues, de la metáfora tradicional, que propone símiles metafóricos entre realidades "próximas" (cabello rubio y oro en Góngora, dientes y perlas en Bécquer), la metáfora vanguardista rompe las relaciones de evidencia y tiende lazos de similitud entre "reálidades más o menos distantes" (23), que no presentan manifiestas posibilidades de vinculación, como en el verso "las calles son tirantes de goma" de Oquedo de Amat, o en el verso "y pensar que la noche, cuando es novia, se desviste" de Hugo Mayo.

En "El reloj caído en el mar", hemos visto varias de estas metáforas, en sus formas sintagmatizadas de comparación o de identificación expresa. Así, para considerar las relaciones en los términos constitutivos de algunas de ellas, observalios que no hay rasgos cosmológicos de similitud entre día y buque sumergido, entre edad y abanico roto o pie desenterrado, entre tiempo y vagos paraguas o campana nunca vista o rosa inundada o medusa. Por lo demás, el rasgo cosmológico dominante de materialidad de los términos segundos de esas metáfoars (buque, abanico, pie, etc.) se opone manifiestamente al rasgo dominante de inmaterialidad de sus términos primeros (día, edad, tiempo), lo que impide una relación tangible, objetiva, entre esas realidades.

Noológicamente, en cambio existen ciertos rasgos de significación que permiten el nexo, y el semantista Stephen Ullmann pareció advertirlo al postular que la labor del poeta consiste en "descubrir ocul-

yo de 1912. Vid.: F. T. Marinetti: Manifiestos y textos futuristas, Barcelona, Ediciones del Cotal S. A., 1978.

(21) Loc. Cit.

(22) En "La imagen", publicado en Nord-Sud No. 13, en marzo de 1918. Vid.: Pierre Reverdy: Escritos para una poética, Caracas, Monte Avila Editores, 1977 p. 25.

(23) Loc. Cit. 
tas analogías y establecer un nexo entre ideas dispares" (el subrayado es nuestro) (24). De esta manera, las relaciones impedidas a nivel cosmológico entre día y buque sumergido, por ejemplo, pueden tenderse en el pensamiento, mediante rasgos que implican una estimación o una clasificación pareja de los hechos o realidades compendidos por la metáfora. La yunción, entonces, se produce a partir de ciertos rasgos o semas de claro estatuto clasemático entrañados por el segundo

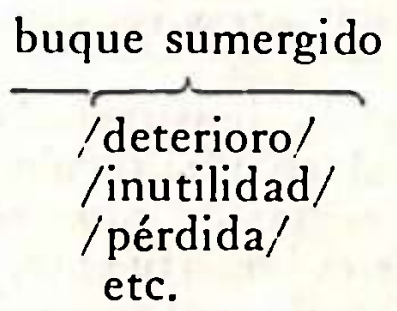

Mediante un proceso que aquí denominaremos "ósmosis semántica", el primer elemento (día) "succiona" los semas clasemáticos vinculados a buque sumergido, para atribuírselos en calidad de sobredeterminaciones adjetivales. Día se reviste así de los desvalores ligados a una embalcación naufragada; se ofrece, entonces, como un día domingo quieto, deteriorado, inútil y perdido.

Este proceso metafórico no permite el traslado hacia día de los otros rasgos semánticos pertinentes a buque sumergido $y$ vinculados a su materialidad (solidez, anegamiento, peso, gravedad), pues de ningún modo podrían ser compatibles con la inmaterialidad de día. La ósmosis semántica es siempre selectiva; $y$, en el caso que nos ocupa, permite el paso y jla åpropiación de aquellos rasgos semánticos que significan una estimación del hecho (día), su clasificación dentro de un orden que suponeluna concepción delo real, aspecto éste que consideraremos más adelante.

\section{5. "Un desvanecimiento de perfumes y razas"}

Vimos que las dos primeras estrofas del poema plantean una situación "actual", con verbos en presente: se trata de un domingo que, por sus correlatos metafóricos o metonímicos de orden marino, debemos suponer ambientado de algún modo en el mar. Vimos también que dicha situación está semantizada de modo negativo, disfórico, a partir de los rasgos de paralización, inutilidad, pérdida y deterioro aportados por los distintos procedimientos metafóricos de la segunda estrofa. Nos resta observar cómo la primera estrofa contribuye, a su vez, a la caracterización disfórica de la situación planteada por el poema.

(24) Citado por Jaime Alazraki: Lo proso norrativa de Jorge Luis Borges. Temas. Estilo. Madrid, Ed. Gredos, 1968; p. 
El verso "ni respiran las hojas" nos remite a otro elemento ambiental: el follaje, para el que resulta pertinente el adjetivo "amarillo" del v. 2. En efecto, decir que no respiran las hojas es sugerir que están muertas, secas; y decir que están secas es añadirles un color, el mismo que ya estab̆a anticipado por el v. 2: "y tantas dimensiones de súbito amarillas". No se requiere más para establecer una ambientación otonal, nutrida de contenidos negativos como: deterioro, marchitez, pérdida, muerte. Sin embargo, no obstante su brevedad, la primera estrofa comprende otros recursos indicativos del otoño, como veremos luego.

El v. 3 contiene un verbo inusitado, "caer", que ya hemos señalado como metáfora verbal en sustitución de "soplar" (la expresión regular debió ser algo así como: "porque no sopla el viento"). El v. 4 posee un verbo que no le es impertinente, "respirar", pero bien puede aceptar en su lugar el verbo entrometido en el verso anterior (la expresión, en tal caso, sería: "ni caen las hojas"). Si aceptamos luego el parentesco semántico entre "respirar" y "soplar", veremos que en los versos en cuestión se presenta un cruce sintagmático-semántico del tipo:

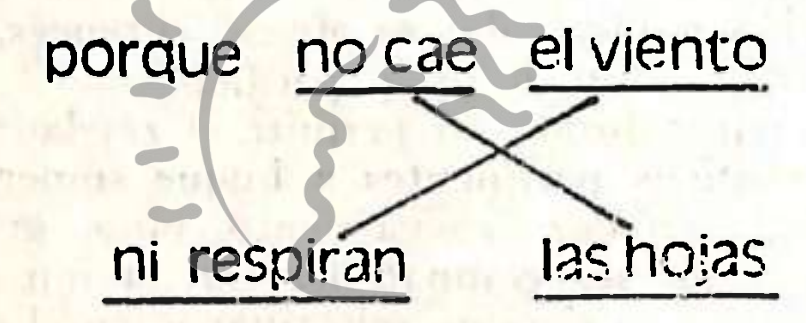

La recomposición planteada en el parrafo anterior, propiciada por el obvio desplazamientoedeum verboo, centrañascierta causalidad cosmológia propia de la estación otoñal: no caen las hojas secas porque no sopla (no respira) el viento. Al preguntarnos por los motivos de la transposición verbal hallamos, en principio, que ella obedece a razones de orden métrico. El poema está construido en base al heptasílabo, actualizando combinaciones que había practicado la poesía modernista: $7,7+2,7+7,7+7+3,7+4+7$. La recomposición atenta, pues, contra la base métrica, y más exactamente contra el heptasílabo que constituye cada uno de los dos versos en cuestión. Por otra parte, la transposición permite caracterizar las hojas como muertas (no respiran), hecho éste que se asocia al dato de amarillez proporcionado por el y. 2 para reconstituir una configuración solventada por la experiencia cosmológica: la del otoño en sus manifestaciones más visibles. Por último, la transposición permite una confusión casi sinestésica que apunta a la unidad en la percepción del fenómeno otoñal.

En consecuencia, el texto promueve disforia desde su estrofa primera, a través de una variedad de situaciones planteadas o sugeridas. como la luz sombría, el pasaje de la primavera, el otoño de pronto establecido ("dimensiones de suibito amarillas"), el deterioro que éste 
entraña, la muerte de las hojas, la ausencia del viento (25). A nivel léxico, basta la sola presencia de términos negativos en esa estrofa para postular su semantización disfórica. Las palabras "sombría" y "amarilla" entrañan negatividad en diferente grado; y las expresiones "no cae" y "no respiran" la hacen explícita.

Al pasar a la tercera estrofa, pasamos de la contemplación del día (este domingo) a la consideración de unidades más amplias de tiempo: meses, años, edades. Pasamos también de un presente concreto, vivencial, a un pasado que se aleja irremediablemente de las posibilidades de retención y recuperación humanas. Explicar esta última afirmación nos obliga a un recorrido que parte de la segunda estrofa. Allí el verso "Es un día domingo detenido en el mar" adelanta la conducta del elemento temporal desarrollada por los versos "Hay meses seriamente acumulados en una vestidura" y "hay años (acumulados - nota nuestra) en un solo ciego signo del agua/ depositada y verde". En estos tres casos el tiempo aparece depositado en algo material que es, respectivamente, el mar, la vestidura y el agua estancada. En otras palabras, una especie de memoria eidética busca ligar. el tiempo a objetos materiales y situaciones concretas, en un intento voluntarioso y al mismo tiempo.afectivo de perennidad ("...una vestidura/ que queremos oler llorando con los ojos cerrados"). Este esfuerzo, que en el poema aparece alcanzando un logro relativo, fracasa ostensiblemente en el caso de la fracción temporal designada con la palabra "edad"; y así tenemos los versos "hay la edad que los dedos ni la luz apresaron" y "hay la nupcial edad de los días disueltos". La oposición entre retención y fuga del tiempo se asocia a la oposición compuesta por la disforia ya vista en las dos primeras estrofas y la euforia que en su presente produjo el tiempo que fugó, al que se asigna el nítido calificativo de "más estimable". Se logra, pues, detener y acumular el tiempo malo, pero huye el del bienestar y la satisfacción. Lo cual puede ser aprehendido en su conjunto mediante la siguiente estructura de sentido de formulación levi-straussiana:

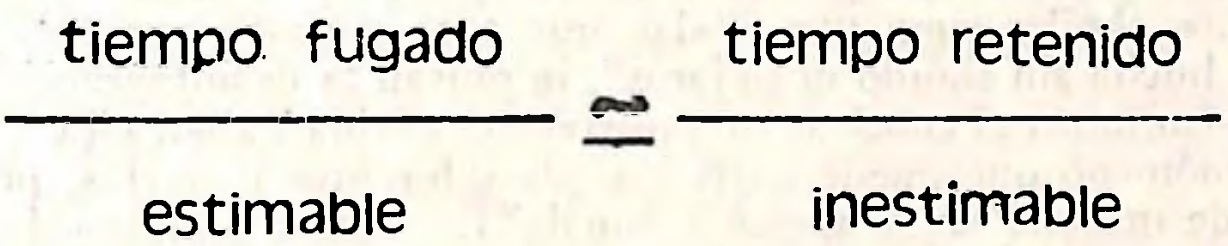

En el punto 1. de este trabajo, vimos cómo la acumulación, el de-

(25) Hay unos versos de Rofael Alberti en que también aparece un otoño disfórico, con incluso alteraciones sintagmáticas que acusan confusión de las percepciones con vistas a la intuición unitaria del fenómeno, pero con un dinamismo que no se da en los versos de Neruda:

Como puntas sangrantes de lanzos rueda el viento

las hojas de los robles...

Pertenecen a El otoño otra vez, Lima, La Rama Florida, 1960; p. 11. 
tenimiento, no es en sí mismo algo loable, pues constituye el preludio del deterioro. El día domingo detenido en el mar es objeto del asalto disolvente de escamas-peces-agua-mar-tiempo total. Análogamente, en la estrofa que ahora nos ocupa los meses están acumulados en un objeto deleznable, sometido él mismo a la labor desintegrante del tiempo cósmico; y los años están retenidos por un agua degradada, cenagosa (piénsese en el carácter anagramático de la aliteración "ciego signo", que contiene el término "cieno"), efímera en función del tiempo total. La retención que propone esta estrofa es, en última instancia, ilusoria.

El siguiente enunciado metalingüístico, puede resumir las últimas constataciones del análisis: el tiempo actual (un domingo de otoño), con toda su negatividad suscitadora de intuiciones disfóricas, está condenado a su disolución, como condenados al agua disolvente (tiempo vasto, cósmico) estuvieron los meses y los años del pasado, y más aún las edades que merecen una reputación estimable y positiva. En otros términos, el decurso del tiempo todo lo iguala; a todo vuelve inútil, irrecuperable y perdido. He ahí una razón de fuerza para una disforia mayor, que depende de la apreciación individual y psicológica del tiempo como un acabamiento.

Estrechamente vinculada a estas últimas constataciones está la progresión metafórica de la cuarta estrofa, que avanza hacia la disgregación material (26). Los términos metafóricos paraguas y campana, de innegable estado sólido, tienen su solidez mediatizada en el texto por el adjetivo o la expresión adjetival, que desdibujan sus contornos y difumina sus cuerpos: "vagos paraguas", "campana nunia vista". Los términos siguientes, rosa y medusa, participan por su naturaleza de los estados sólido y líquido, con una marcada preferencia por el segundo, que determina que sur condición sea menos estable o menos "material". En el caso de rosa, esa condición está resaltada en el poema por el adjetivo "inunfadà. "El témino" que sigue, latido, aumenta la desmaterialización de la cadena de símiles al presentar un fenómeno antes que un estado del ser material. Más aún, este fenómeno está desdibujado por el adjetivo que se le asocia, "quebrantado". Los símiles siguientes, "algo que toca y gasta apenas" y "uná confusa huella sin sonido ni pájaros", impulsan la desintegración material del conjunto al concitar una misteriosa entidad abstracta ("algo") o un fenómeno que puede participar de diferentes materias, pero que carece de materia en sí mismo ("huella"). Con el añadido de que el elemento material asociable a huella estaría de antemano desnaturalizado por diferentes negaciones: "confusa", "sin sonido ni pájaros". El verso final de esa estrofa, "un desvanecimiento de perfumes y ra-

(26) En su trabajo sobre "El reloj..." Amado Alonso considera detenidamente la "progresiva desmaterialización de lo contemplado". (Op. cit.: p. $41)$ en la cuarta estrofa. Concibe la secuencia metafórica del caso como una serie de intentos de plasmación de la intuición poética, en que caben las vacilaciones y las rectificaciones ("pero no es eso, es...") propias del proceso creador. 
zas", extrema la disgregación y deja insinuado el imperio de su condición límite, la inmaterialidad, en que se pierden no sólo los perfumes, sino también algo mucho más apreciable, las razas -entendidas sin duda como generaciones-, y con ellas la humanidad entera, el hombre.

Si bien se observa, la cuarta estrofa constituye un repertorio de menciones sensóreas que cubren cuatro de las cinco vías u órganos de percepción. Anotadas en orden las menciones correspondientes a cada sentido, se hace evidente no sólo la progresión hacia la inmaterialidad de los objetos percibidos, sino la culminación de cada serie en una suerte de dificultad y aun de imposibilidad de la percepción (bajo las líneas del siguiente cuadro se sitúan los enunciados que rectifican el ser del tiempo humano: "pero no es eso, es..."):

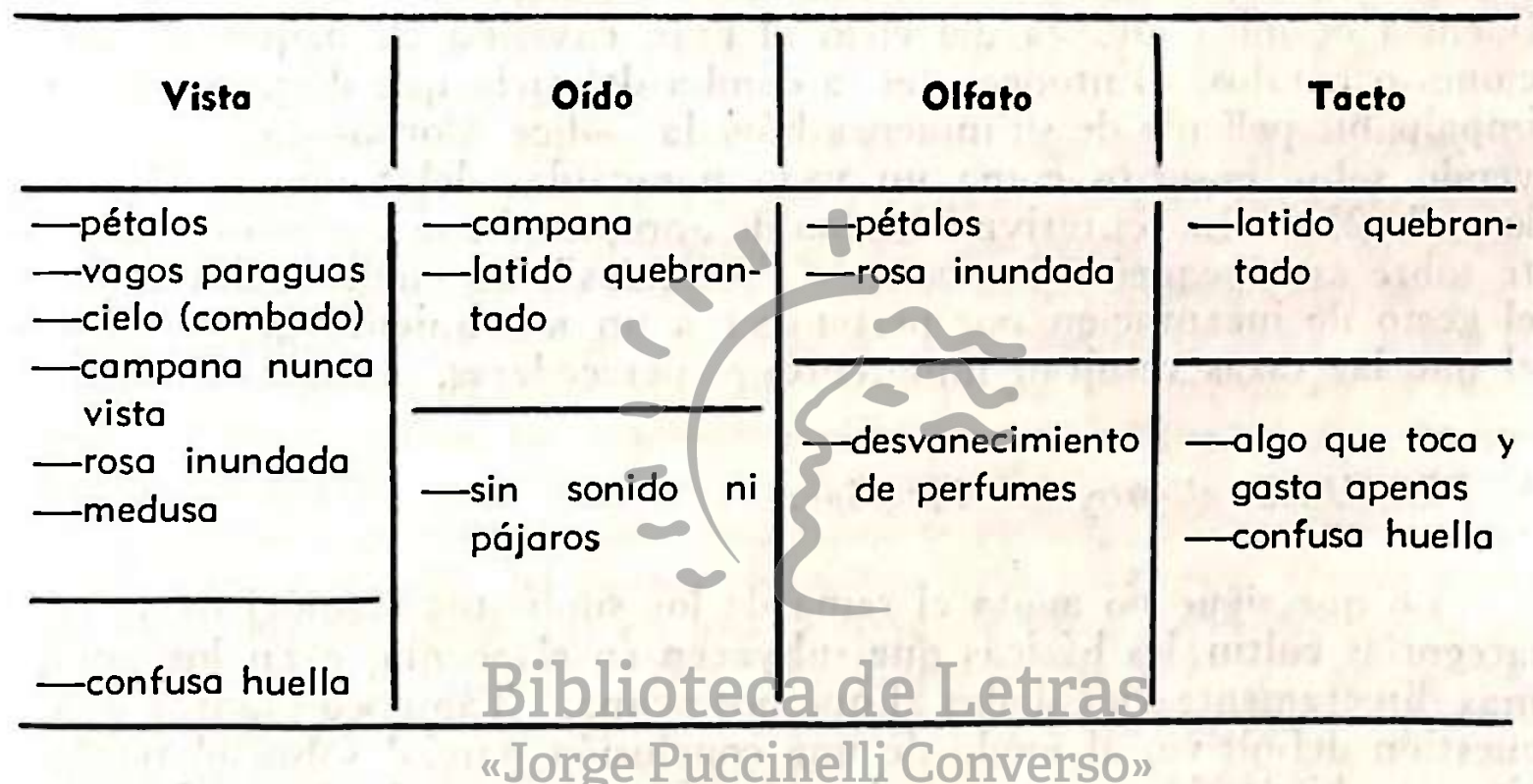

Podemos afirmar que los tres últimos versos de la cuarta estrofa son signo inequívoco de la liquidación del tiempo humano en el tiempo total y también del fracaso de los sentidos humanos en la captación del tiempo-reloj una vez que éste cae y se sumerge en el tiempomar; entonces ya no se le puede ver, ni oúr, ni oler con discernimiento. En otras palabras, esos versos son signo de la impotencia del hombre por conocer acerca de "su" tiempo.

Las menciones que atañen al oído, curiosamente están caracterizadas por la isocronía. Aquello que es audible en esta estrofa - y en el poema - tiene un ritmo, una dinámica regular y pareja. Está en el latido antes de ser declarado quebrantado, en el tañer de la campana y en el tic-tac del reloj. Tal isocronía entra, por cierto, en correspondencia con las fracciones de tiempo referidas por el texto (días, meses, años) o implicadas por él (horas, minutos, segundos). Al declarar el poema quebrantado al latido y luego inaudible, así como irregular, al fenómeno ("confusa huella sin sonido..."), está comprometiendo todas las demás regularidades del texto, y condicionándolas 
a su quebranto y disolución. D ese modo el texto produce una degradación masiva del tiempo humano (de los concretos tiempos humanos, vivenciales, experienciales), más que una degradación parcial sujeta a los escasos símbolos con que juega el poema (reloj, pétalo...).

Las menciones que corresponden a la vista tienen, a su vez, un rasgo común: la línea curva, combada, cóncava o convexa, observable en el cielo, el paraguas, la campana, la rosa y la medusa, y quizá también en el mar si nos atenemos a la vastedad cósmica con que es considerado este símbolo en el poema. Amado Alonso explica este común denominador de las imágenes visuales a partir de la identificalción de tiempo y espacio. En efecto, la vastedad hace al tiempo total equiparable no sólo al mar, sino al espacio celeste. El tiempo total, en "El reloj caído en el mar", se convierte así en una colosal fluencia cósmica que va del cielo al mar, cayendo en pequeñas porciones o pétalos. Entonces "es la comba del cielo que desprende una impalpable película de su inmensa bóveda - dice Alonso-, que va cayendo sobre nosotros como un vago paracaídas del tamaño del cielo..." (27). La tentativa humana de apropiación se cierne justamente sobre esas pequeñas porciones o "películas", las cuales desatienden el gesto de incautación por pertenecer a un movimiento eterno ante el que las razas resultan impotentes y perecederas.

\section{Hacia el proyecto ideológico}

Lo que sigue no agota el tema de los supuestos ideológicos y las categorías culturales básicas que subyacen en el poema, o en los poemas directamente vinculados al que nos ocupa. Tampoco plantea una cuestión definitiva, «abmodo decuna conclusión parcial sobre cl tema, sino una hipótesis que, como tal, está sujeta a comprobaciones de mayor envergadura, en que tendría lugar el estudio de las relaciones profundas entre la estructuración textual y las cuestiones de orden ideológico.

La sola vez que el poeta de "El reloj caído en el mar" alude al hombre plural (razas) lo hace para señalar la suerte de fatalismo a que está destinado, esto es, su extinción, su anulación. El poema plantea la disolución de las generaciones por efecto de la acción inexorable y degradante de un tiempo cósmico desprovisto de condiciones humanas, de alcances, proyectos, actividades y sustancias humanas. Tal como si con cada generación acabase una parcela aislada y precaria de tiempo, y tal como si la historia no jugase el papel de un incesante continuum de relaciones e interacciones dialécticas. Podemos afirmar, en suma, que este texto niega la historia en su sentido correcto.

(27) A. Alonso: Op. Cit.; p. 40. 
Por otra parte, la memoria esbozada por la tercera estrofa está limitada a un papel individual, no sólo porque está entendida como una práctica personal, sino también porque está destinada a ser ejercitada sobre instantes y experiencias privadas de la vida pasada del individuo (en este sentido, la última estrofa del poema documenta suficientemente sobre el carácter privado de la evocación). Nada tiene que ver esta memoria con la memoria colectiva cristalizada en la tradición o en las tradiciones de un pueblo. Además, no se ocupa de acontecimientos colectivos, o de aquellos que teniendo un origen individual repercuten socialmente. $Y$, por último, carece de proyecciones de futuro, pues la perspectiva en que se sitúa el poeta o hablante básico del texto, apunta sólo hacia el pasado y está negada a toda consideración sobre el porvenir. Esa es la opción del poeta. Y es allí que comenzamos a tener conocimiento del proyecto ideológico que anima el texto del análisis.

Ya sabemos por las lecciones de Georg Lukács, contenidas en su libro Significación actual del realismo crítico, que esta postura estatizante de la historia es característica de la literatura de vanguardia, y que ella alcanzó con los Poemas estáticos de Gottfried Benn su punto culminante. "El rechazo de toda relación poética y filosófica con el porvenir - dice Lukács- es, pues, para Benn, el criterio de la sabiduría. Pero incluso los representantes del vanguardismo que no rechazan con este rigor la historia, la evolución, etc., y que tienen la preocupación de describir literariamente el presente o el pasado inmediato (sería el caso del primer Neruda - nota nuestra), transforman el suceder histórico-social en una especie de estaticidad, hacen de su movilidad algo inmutable" "(28) En lo que a "El reloj..." concierne, vemos que allí no sólo se hace estático el tiempo humano (considérense los meses y los "años"seriamente acumulados"), sino que fraccionado en parcelas aisladas se desvanece en un imperioso flujo (o estado) supra-humano e inabordable como el mar o el cosmos; un flujo que es más bien una entidad abstracta, un concepto, una categoría al modo de los universales del idealismo. Por eso las relaciones entre el tiempo humano y el yo lírico en que transparenta el poeta (relaciones que son también el referente de "El reloj..."), se establecen como una interiorización de esa realidad material, para convertirse en pura sustancia psíquica, desprovista de sus cualidades objetivas y materiales. Así el tiempo no provoca otra cosa que disforia. Desposeído de su realidad material, no puede producir más que ilusiones, como la de su recuperación (fallida) por vías de la memoria eidética. El tiempo psicológico jamás se recupera; en tanto que el tiempo histórico es siempre una realidad actuante sobre cada momento del presente y con posibilidades de acción real sobre el futuro. El tiempo, como categoría psicológica o abstracta, jamás podrá explicar las relaciones del hombre con el mundo en su sólito vivir.

(28) Georg Lukács: Significación octual del realismo crítico, México, Ediciones Era, 1967; p. 42. 
Individualismo, subjetivismo exacerbado, estatismo, contemplación disfórica del presente y de un pasado irrecuperable, soledad cuasi solipsista y ausencia de un movimiento dinámico hacia el futuro constituyen, a la luz de nuestro análisis, los componentes básicos de sentido de "El teloj caído en el mar". Y también, en gran medida, los que animan la escritura de la primera época poética de Neruda que culminará en 1936. Por lo demás, esos componentes son, en su mayoría, los caracteres generales del vanguardismo, según el agudo estudio de Lukács que ya hemos mencionado (29).

No pretendemos en absoluto restarle calidad poética ni belleza a la poesía del primer Neruda. Estamos lejos de insinuar, por otra parte, que los postulados ideológicos de esa escritura la descalifiquen funcionalmente ante su época, pues correspondió de manera admirable - dentro del vanguardismo no sólo hispanoamericano, sino generala la tarea de renovación sustancial de la literatura, tarea que se impuso como corolario del nuevo ordenamiento social, político y económico que trajo a la sociedad occidental la primera post-guerra. Sí es interés nuestro remarcar cómo en la siguiente época de la poesía de Neruda, cuyo inicio coincide con el estallido de la Guerra Civil Española, vivida más o menos directamente por el poeta chileno, su proyecto ideológico - y su práctica - cambió de manera radical.

En efecto, a patir de la Tercera residencia ingresa a la lírica de Neruda una concepción materialista del tiempo; y con ella, la historia entendida como la lucha del hombre para asegurarse los medios de producción material de su vida, y una orientación hacia el futuro, como un proyecto social y no sólo individual. Basta mencionar el conjunto de poemas titulado "España en el corazón", como un esclarecido documento de esta sustancial variación ideológica. "Jorge Puccinelli Converso"

Lima, U. de San Marcos, octubre de 1980. Caracas, CELARG, mayo de 1980.

\section{Passim.}

(29) Ibid.: capítulo sobre "Los principios ideológicos del vanguardismo"; 